other insects several generations produced by parthenogenesis ${ }^{1}$ intervene between true sexual generations.

The typical case is that of the Aphides, which has been long known; here there is little difference of habit or structure except as regards wings, and possibly the generative organs.

Some of the Aphides, however, do show modifications in their life-history almost as remarkable as in the case of the Cynipidæe mentioned above. Lichtenstein's researches, though vigorously attacked by some French writers, have been confirmed by Kessler and Horvath. $\mathrm{He}$ observed that the Aphides, living during summer at the roots of various grasses, become winged in autumn and fly to the trunks of trees, where they produce sexual individuals ; the solitary egg of the female remains dormant in her dried body till the following spring, when it develops into a gall-making aphis, the foundress pseudogyne. This produces viviparous winged young (emigrant pseudogynes), which in June fly back to the grass, lose their wings, and produce fresh generations by parthenogenetic eggs. This completes the cycle, and the generations distinguished by habitat are often different in appearance, even a large number of different forms being sometimes thus connected. For instance-

Phylloxera quercus (Balbiani) migrates from Quercus ilex to $Q$. sessiliflora.

$P$. vastatrix, from the leaf-galls to the root of the vine.

Tetraneura rubra, from galls on trunk of elm to roots of dog's grass.

T. ulmi, from elm-galls to roots of maize.

Other less perfect examples of heterogamy, such as Cecidomyia and Ascaris nigrovenosa, are well known.

The current views concerning the probable origin of the phenomena of heterogamy and metagenesis may be roughly classed in two groups, one formulated by Leuckart and supported by Claus and Balfour, the other held by Salensky and Brooks.

Leuckart supposed that alternation of generations is a division of labour in regard to reproduction in which the two chief kinds of multiplication, sexual and asexual, are divided between different individuals and generations.

The other theory is that these phenomena are due to a modification of metamorphosis, Salensky also stating that "the connection between metagenesis and metamorphosis is much more easily seen in Tunicates than in other animals."

If in an animal undergoing a metamorphosis the larva acquired the power of producing other individuals by budding, we should have the larval form undergoing finally a change into the adult sexual form. At the same time it is obvious that this is not an indispensable condition; for the more individuals the larva produced the more incapacitated it would be for future sexual reproduction, so that in all probability there would soon be no development beyond the larval stage. W. K. Brooks, in a recent paper on the subject, alludes to a medusa, Cunina, the hydroid form of which is parasitic on the stomach of another medusa, Turritopsis. This hydroid produces medusæe by gemmation, but is itself finally modified into a medusa.

The contrast between this and the more usual case is thus :-

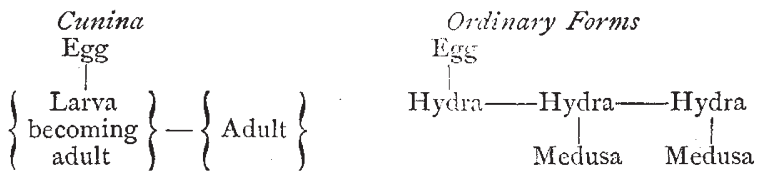

Similarly in the Cestodes it is ustally allowed that the Echinococcus stage consists in the production of a number of individuals in the larval state, not of adults differcntiated to meet diverse methods of reproduction.

In such a form as Doliolum, and incleed generally among the Tunicata, there seems to be more difficulty attending this view. Gemmation does not result in the production of individuals like the gemmating zooid, which by growth become unlike it. The cyathozooid, or the Doliolum with dorsal stolon, not only do not become sexual after a metamorphosis, but they give rise to the ascidiozooid, a form with ventral stolon in no way comparable to the adult of which it is the arrested larva. It seems here more probable that the existence of two methods of reproduction perhaps taking place at slightly different times has led to the selection of two sets of individuals, one better fitted for gemmation, the other for sexual reproduction. We must then suppose that any influence acting for the modification of one generation is transmitted not to the next but the next but one.

I Huxley's distincticn of tric ova ard t seud-ova ani ears i. ot to hol't.
This is, however, in no way more strange than the transmission of sexual characters.

While, however, the case of the Tunicates may be considered doubtful, it will probably not be denied by unprejudiced observers that the phenomena seen in the Insecta are more easily accounted for by Leuckart's hypothesis than by Salensky's.

It would seem that there could be no ground for saying with regard to the Gynipidæe, that in a group of which it is characteristic that only the mature forms, and sometimes not even those, are winged - one winged form is the larval condition of another which is smaller, but not otherwise very different, yet this is the case in Dryophanta scutellaris-Spathegaster taschenbergi.

It is probable, then, that these methods of reproduction have not had in all cases the same origin, and, as in several other instances to which attention has been paid during the last few years, the resemblances, which occur in various animals in no way connected but distributed over almost the whole animal kingdom, may best be considered as homoplastic, that is as brought about in different ways under the influence of similar conditions of life.

R. N. G.

\section{THE PARIS ACADEMY OF SCIENCES}

$T H E$ yearly public meeting of this body was held on Monday,

May 5, under the presidency of M. Emile Blanchard. The proceedings consisted mainly of a detailed statement of the awards made for prize essays or distinguished services rendered during the year 1883 to the various branches of the mathematical and natural sciences, useful arts, and industries.

In Mechanics the Extraordinary Prize of 6000 francs, established to encourage improvements of all sorts in the efficiency of the French Naval Service was divided, as in previous years, amongst several candidates. For his "Studies on Marine Engines," now in course of publication, M. Taurines received 3000 francs, M. Germain 2000, for his "Treatise on Hydrography," and Capt. A. de Magnac I000, for his "New Astronomic Navigation," published in 1877 . The Montyon Prize, in the same department, was also divided, half going to M. Léon Francq, for his improvements in Lamm's steam traction engine, and half to Capt. L. Renouf, inventor of an instrument intended to simplify the observation of altitudes at sea, dispensing with the necessity of employing artificial horizons and enabling exact calculations to be made without stopping the vessel under sail or steam. M. Jacquemier, inventor of the kinemometer, dynamometer, and other useful appliances, gained the Plumey Prize ; and M. Marcel Deprez the Fourneyron, for his ingenious electric experiments on the Chemin-de-fer du Nord.

The Lalande Prize, founded by the illustrious astronomer to stimulate astronomical studies in France and abroad, was unanimously decreed to MM. Bouquet de la Grye, de Bernardières, Courcelle-Seneuil, Fleuriais, Hatt, Perrotin, Bassot, Bigourdan, and Callandreau, chiefs of the various French expeditions sent to observe the transit of Venus on December 6, 1882. In this branch the Valz Prize was assigned to M. Stephan, Director of the Marseilles Observatory, and discoverer of about 700 nebulæ, the positions of over 500 of which he has carefully determined.

For his extensive labours in the field of Experimental Physics M. Henri Becquerel was rewarded with the Lacaze Prize, the only une given away in this department.

In Chemistry the Jecker Prize was secured by M. Etard for his numerous researches and publications on organic chemistry. M. L. Cailletet obtained in this branch the Lacaze Prize for his important researches on the liquefaction of gases, and esper ally for his success in, for the first time, demonstrating the possibility of liquefying all the so-called permanent gases.

In Geology the Grand Prize granted by the Minister of Finance for the best geological description of any region in France or Algeria fell to M. Fontannes for his long and successful researches in the Tertiary Basin of South-East France, minly embodied in his "Stratigraphic and Palæontological Studie; of the Tertiary Period in the Rhone Valley." $\Lambda$ n exceptional award of 2000 francs was also made in favour of M. Péron, author of an extremely important work entitled "Essay on a Geological Description of Algeria."

For his comprehensive monograph on Trichinosis, M. Joannès Chatin, Director of the Government Laboratory at Havre, obtained the Barbier Prize; and MM. G. Bonnier and L. Mangin the Desmazières Prize for their memoir on the "Respiration and Transpiration of Fungi," both in the department of Botany. In the same department M. Costantin was the successful competitor 
for the Bordin Prize, awarded for the best solution of the following question proposed in 1879 by the Academy :-- "Explain by direction observation and experiment the infuence exercised by the environment on the structure of the root, stem, and leaves of vegetable organisms. Study the modifications undergone in water by land plants and those experienced by aquatic plants compelled to live in the air. Explain by direct experiments the special forms of some species of marine flora." .

In Agriculture the Morogues Prize was gained by M. Duclaux for his great work on "Biological Chemistry," forming part of the "Chemical Encyclopædia" published under the direction of M. Fremy.

In Anatomy and Zoology the Grand Prize granted by the Minister of Finance for the best memoir on the "Histological Development of Insects during their Metamorphoses," as proposed by the Academy, was assigned to the young naturalist, Dr. H. Viallanes, for his " Researches on the Ilistology of Inscets, and on the Histological Phenomena accompanying the post-embryonic Development of these Animals." In the same department the Bordin Prize was awarded to M. Grand'Eury, who, in two memoirs entitled "Carboniferous Flora of the Department of the Loire and Central France," and "On the Formation of Coal," deals satisfactorily with the "Botanical or Zoological Palæontology of France or Algeria," as proposed by the Academy to competitors for this prize.

Subjoined are somc of the most important prizes proposed for I 884 and following years :-

Bordrn : General Study of Monge's Problem of Earthworks.

Francerur: Works or discoverics useful to the progress of the pure and applied mathematical sciences.

The Extraordinary Prize of 6000 Francs: Studies tending to increase the efficiency of the French Naval forces.

PONCELET: Awarded to the anthor of the most useful work in advancing the pure or applied mathematical sciences.

PLUMLY : For improvements in steam-engines or any other iuvention contributing most to the progress of steam navigation.

Grand Prize of the Mathematical Sciences : For any important advance in the theory of the application of electricity to the transmission of force.

VAILLANT : Fresh researches on fossils made in any region which for the last quarter of a century has been little explored from the palæontological standpoint.

DESMAZIERES : For the most useful work"on the cryptogamous plants.

Grand Prize of 'ine Physical Scrences: On the mode of distribution of marine animals along the French seaboard. I 885

DELMONT: To engineers, for the best work connected with the Department of Public Works (Roads and Bridges).

FOURNLYRON : Theoretical and practical study on hydraulic accumulators and their applications.

DAMOISEAU : Review of the theory of Jupiter's satellites.

Grand Pkize of the Matmematical Sciences: Study of the clasticity of one or several crystallised bodies from the experimental and theoretical standpoints.

BORDIN : Rescarches on the origin of atmospheric electricity, and on the causes of the great development of electric phenomena in thunderstorms.

I. LACAZE : For the best treatise on physics, chemistry, and jhysiology.

DELesse : For a work on geological sciences, or, failing this, on mineralogical sciences.

MONTAGNE: For important works on the anatomy, physiology, development, or description of the lower cryptogamous plants.

Grand Prize of the Physical Scrences: Study of the intimate structure of the tactile organs in one of the chief natural groups of Invertebrates.

BORDIN : Comparative study of the freshwater fauna of Africa, Southern Asia, Australia, and the Pacific Islands.

GAY : Measure of the intensity of weight by the pendulum.

Cuvice : For the most important treatise either on the animal kingdom or on geology.

PETIT D'ORMOY: Pure or applied mathematical sciences and the natural sciences.

De xa Foxs Mrrocen: For the best treatise on the flora of North France.
I 887

Chaussier: For important works on legal and practical medicine.

1893

Morogues: For the most useful work in stimulating the progress of agriculture in France.

\section{SOCIETIES AND ACADEMIES \\ LONDON}

Royal Society, April 24.--" On the Relation between the Electrical Qualities and the Chemical Composition of Glass and Allied Substances." Part I. By Thomas Gray, B.Sc., F.R.S.E., and Andrew Gray, M.A., F.R.S.E., Assistant to the Professor of Natural Philosophy in the University of Glasgow, and J. J. Dobbie, M.A., D.Sc. (Edin.), Assistant to the Professor of Chemistry in the University of Glasgow. Communicated by Prof. Sir William Thomson, F.R.S.

This paper describes some further experiments as to the relation between the chemical composition of glass and its quality of resistance to electrical conduction through its substance.

The experiments were made on specimens of flint glass of different densities, made by different makers, and varying considerably in chemical composition. The method of experimenting was that described in Mr. T. Gray's paper on the same subject (Proc. R. S., No. 222, 1882). Each of the specimens, which were in the form of globular flasks of nearly three inches in diameter, was filled up to the bottom of the neck witl mercury, and immersed to the same level in mercury contained in an outer vessel. $A$ wire dipping in the mercury within the flask was connected, without touching the table or any of the supports, to one terminal of a sensitive galvanometer of high resistance, and the circuit completed, through a battery of about 120 Daniell's cells, from the other terminal to the mercury in the outer vessel. ('The galvanometer was well insulated, and was the high resistance astatic instrument described in Proc. $R$. S., February 14, 1884.) The outer vessel, containing the flask, was immersed in a sand-bath which was heated by a Bunsen burner to temperatures above $100^{\circ} \mathrm{C}$., and readings of the galvanometer taken at different temperatures, with precautions to insure that there was no error due to leakage. By means of a suitable reversing key in the circuit, the direction of the electrification, which lasted in each case about three minutes, was reversed between each pair of readings. From the observed deflections, and the constants of the galvanometer and battery, which were frequently determined, the resistance of the flask at each temperature could be calculated.

The results of the electrical experiments and of complete analyses of the specimens of glass are detailed in the paper, and show that the specific resistance of glass of the kinds experimented on increases with the percentage of lead contained in the glass and also with the density; and that further, as had been previously found by different experimenters, the resistance diminishes as the percentage of alkali present in the glass increases. The best specimen experimented on contained over 40 per cent. of oxide of lead, and had a density of $3.14 \mathrm{I}$, and a specific resistance at $130^{\circ} \mathrm{C}$. of $8400 \times 10^{10} \mathrm{ohms}$ between two opposite faces of a centimetre cube. From this result, as it has been found by these and former experiments that the resistance is halved, over a considerable range of temperature, by an increase of temperature of about $81_{2}^{\circ} \mathrm{C}$., the approximate resistance of the glass at other temperatures may be found.

The paper concludes with a short statement of further work which the authors have in hand with respect to the electrical qualities of glass and minerals.

Linnean Society, May I.-Prof. P. Martin Duncan, F.R.S., vice-president, in the chair.-Messrs. Wm. Dennison-Roebuck and F. Newton-Williams were elected Ordinary Fellows, and Profs. E. Hacckel of Jena, A. Kowalevslyy of Odessa, and S. Schwendener of Berlin, Foreign Members of the Society. -Mr. S. O. Ridley exhibited and made remarks on a series of drawings of sponges (and their spicula) and of Actinize drawn from the living objects, as obtained in Ceylon and forwarded by Dr. W. C. Ondaatje, F.L.S.-Prof. Jeffreys Bell also drew altention to sketches of living Ceylonese Comatulids sent by Dr. Ondaatje as an earnest of progress in researches on the marine fauna of that coast.-Mr. T. Christy showed the leaf of a China grass rich in fibre useful for textile purposes.-Mr. R. Eowdler Sharpe rcad a paper on a collection of birds from 